\title{
LITERASI INTERNET PADA SISWA SEKOLAH MENENGAH PERTAMA
}

\author{
Noneng Sumiaty \\ Balai Pengkajian dan Pengembangan Komunikasi dan Informatika Bandung (BPPKI) Bandung \\ J1.Pajajaran No.88 Bandung-40173, Jabar, Telp.022-6017493, Fax.022-6021740 \\ HP.08122303764.E-mail: nsumiaty62@gmail.com \\ Neti Sumiaty \\ Balai Pengkajian dan Pengembangan Komunikasi dan Informatika Bandung (BPPKI) Bandung \\ J1.Pajajaran No.88 Bandung-40173, Jabar, Telp.022-6017493, Fax.022-6021740 \\ HP.0811220846.E-mail: hanetihasan@gmail.com \\ Naskah diterima tanggal 27 Oktober 2013, direvisi tanggal 20 Mei 2014, disetujui tanggal 4 Juni 2014
}

\section{LITERACY INTERNET ON HIGH JUNIOR SCHOOL STUDENTS}

\begin{abstract}
Internet literacy can be used to acknowledge the world's growth in many sectors as quickly and accurately, as well as in education. The focus of this research is what level of internet literacy in students of SMPN 8 Purwakarta? This purposes of this research is to obtain information about the level of internet literacy in students of SMPN 8 Purwakarta. The method used in this research is descriptive qualitative. The study population was all students in grade 8 , while the sample was two students taken from each classes. There are 7 classes of grade 8 . So the overall sample was 14 informants. The theory used is adopted from Ciolek, Matthew (2003) on the understanding of internet which consists of: basic skills, moderate skill, and advanced skills. The results showed that only a few informants have extensive knowledge of the overall level of mastering the internet. Most of the students of SMP 8 only master and understand the basic rate only. Students of SMP 8 are expected to master and understand all levels of understanding of the Internet gradually.
\end{abstract}

Keywords: literacy, internet, education, and junior high school students.

\begin{abstract}
Abstrak
Literasi internet sangat diperlukan untuk mengetahui perkembangan dunia dalam berbagai hal secara cepat dan tepat, begitu juga dalam dunia pendidikan. Fokus penelitian ini adalah: Bagaimana tingkat literasi internet pada siswa SMPN 8 Kabupaten Purwakarta? Tujuan penelitian ini untuk mendapatkan informasi tentang tingkat literasi internet pada siswa SMPN 8 Kabupaten Purwakarta. Metode yang digunakan dalam penelitian ini adalah deskriptif kualitatif. Populasi penelitian adalah seluruh siswa kelas 8, sedangkan sampel diambil dari tiap kelas dua siswa; sementara siswa kelas 8 ada 7 kelas. Jadi, keseluruhan sampel berjumlah 14 informan. Teorinya diadopsi dari Ciolek, Matthew (2003) tentang pemahaman dan penguasaan internet yang terdiri dari: basic skill, moderate skill, dan advanced skill. Hasil penelitian menunjukkan bahwa hanya sedikit informan yang telah menguasai dan memahami secara keseluruhan tingkat tentang penguasaan internet. Sebagian besar siswa SMPN 8 hanya menguasai dan memahami tingkat dasar saja. Diharapkan siswa SMPN 8 mengusai dan memahami seluruh tingkatan pemahaman internet secara bertahap.
\end{abstract}

Kata kunci: literasi, internet, pendidikan, dan siswa SMP. 


\section{PENDAHULUAN}

Agenda World Summit on the Information Society (WSIS), di Jenewa pada tahun 2003 dan di Tunisia tahun 2005 adalah membangun masyarakat informasi pada tataran global dengan sasaran terwujudnya masyarakat global. Sementara di Indonesia visi Masyarakat Informasi Indonesia harus tercapai pada tahun 2015. Konsekuensi atas kesepakatan WSIS menjadikan informasi bersifat borderless, dapat mengalir ke mana saja tanpa batas negara. Perkembangan teknologi dan informasi yang pesat memungkinkan siapa pun dapat mengakses, menggunakan, dan berbagi informasi serta pengetahuan. Seiring dengan ledakan informasi dan penerapan Teknologi Informasi dan Komunikasi (TIK) tersebut, masyarakat akan berkembang memasuki peradaban masyarakat informasi (information society), yaitu peradaban di mana informasi sudah menjadi komoditas utama dan interaksi antarmanusia sudah berbasis teknologi informasi dan komunikasi (Haryati, 2011).

Untuk penguasaan informasi, diperlukan suatu keterampilan tentang penguasaan pada huruf atau keaksaraan, namun perkembangan ilmu pengetahuan dan teknologi melahirkan tantangan yang menuntut manusia memiliki kemampuan literasi lain, di luar melek huruf; seperti literasi informasi dan literasi media (termasuk media baru/internet).

Berkenaan dengan literasi, telah dilaksanakan Konferensi Tingkat Tinggi (KTT) di Berlin, Jerman pada 7-8 Maret 2002. Konferensi tersebut diberi nama 21st Century Literacy Summit. KTT ini menghasilkan "buku putih" yang diberi judul 21st Century Literacy in a Convergent Media Word (Depkominfo, 2006).

KTT ini mengidentifikasi standarstandar literasi untuk abad ke-21 dikaitkan dengan tantangan yang dihadapi serta sejalan dengan perkembangan ilmu dan teknologi. Berdasarkan identifikasi tersebut direkomendasikan pada berbagai institusi cara-cara mendukung individu-individu agar bisa memetik manfaat dari perangkat dan sumber daya pada abad digital.

Dalam buku putih disebutkan, literasi abad ke-21 lebih dari sekadar literasi tradisional yang berbasis membaca, menulis, matematika, dan ilmu pengetahuan. Konsep baru literasi memasukkan komponenkomponen berikut ini untuk memperkaya pengetahuan dan keterampilan berfikir kritis manusia dengan memadukan perkembangan sosial, profesional, dan teknologi, yakni: 1) Literasi teknologi: kemampuan untuk memanfaatkan media baru seperti internet untuk mengakses dan mengomunikasikan informasi secara efektif; 2) Literasi informasi: kemampuan untuk mengumpulkan, mengorganisasikan, menyaring dan mengevaluasi informasi dan untuk membentuk opini yang kokoh berdasarkan kemampuan tersebut; 3) Kreativitas media: kapasitas individu yang terus berkembang di mana pun untuk membuat dan menyebarluaskan konten pada berbagai khalayak; 4) Tanggung jawab dan kompetensi sosial: kompetensi untuk memperhitungkan akibat-akibat sosial dari publikasi online dan tanggung jawab terhadap anak-anak (Bertelsmann dan AOL Time-Warner dalam Iriantara, 2009).

Literasi di era digital mutlak diperlukan, mengingat perkembangan ilmu pengetahuan dan teknologi berlangsung sangat cepat. Begitu juga dengan literasi internet sangat diperlukan, karena dengan internet seseorang bisa mengetahui apa yang diinginkan secara tepat dan cepat. Dunia seolah di tangan manusia, waktu, dan ruang tidak menjadi masalah.

Saat ini internet bukan hanya digunakan sebagai sarana komunikasi ataupun sarana mencari informasi, tetapi juga telah digunakan sebagai sarana untuk pemenuhan hampir semua kebutuhan, termasuk kebutuhan pendidikan, hiburan, dan rumah tangga; bahkan bisa dijadikan sebagai sarana pencari uang. Harga tarif akses internet pun saat ini lebih murah jika dibandingkan dengan beberapa tahun lalu. Pengguna akses internet pun bukan hanya orang yang berada di wilayah perkotaan, orang yang tinggal di perdesaan pun juga dapat mengakses internet. 
Pengguna internet awalnya hanya terbatas pada orang-orang kota yang berekonomi dan berpendidikan tinggi. Namun, saat ini pengguna internet sudah merambah ke berbagai pelosok tanah air dan pada masyarakat yang berpendidikan dan berekonomi menengah ke bawah, serta anakanak dan para remaja sampai orang dewasa termasuk siswa Sekolah Lanjutan Pertama di Kabupaten Purwakarta. Fokus penelitian ini adalah: bagaimana tingkat literasi internet pada siswa SMPN 8 Kabupaten Purwakarta? Tujuan penelitian untuk mendapatkan informasi tentang tingkat literasi internet pada siswa SMPN 8 Kabupaten Purwakarta.

Kegunaan penelitian diharapkan dapat menjadi masukan berharga bagi pemerintah sebagai pembuat kebijakan, dalam hal ini Kementerian Komunikasi dan Informatika tentang literasi internet bagi para siswa.

\section{LANDASAN KONSEP}

\section{Penelitian Terdahulu}

Penelitian dengan judul "Pengaruh Pemanfaatan Internet terhadap Peningkatan Literasi Informasi Pengguna pada Badan Perpustakaan Arsip dan Dokumentasi Provinsi Sumatera Utara" oleh Siahaan, Shella Anne Tryssa P, Universitas Sumatera Utara. Penelitian ini adalah termasuk jenis penelitian paradigma deskriptif asosiatif. Hasil pengolahan data menunjukkan bahwa $20,2 \%$ variabel literasi informasi dapat dijelaskan oleh variabel pemanfaatan internet. Sedangkan sisanya sebesar 79,8\% merupakan pengaruh dari variabel lain yang tidak dijelaskan pada penelitian ini (Siahaan, 2010).

Kajian lain adalah berjudul "Literasi Internet dan Partisipasi Politik Masyarakat Pemilih dalam Aktivitas Pemanfaatan Media Baru" oleh Bambang Mudjiyanto dari Balai Pengkajian dan Pengembangan Komunikasi dan Informatika (BPPKI) Jakarta. Penelitian menggunakan survei terhadap 100 responden yang diambil menggunakan teknik sampling acak sederhana. Masalah pokok penelitian tersebut menyangkut pemanfaatan media baru untuk kepentingan melakukan partisipasi politik oleh masyarakat pemilih dan menyangkut keterkaitan partisipasi politik dengan faktor literasi internet. Keterkaitan partisipasi politik dengan faktor literasi internet, berdasarkan hasil pengujian hipotesis menunjukkan di antara kedua variabel memiliki hubungan signifikan (Mudjiyanto, 2012).

Sementara penelitian yang penulis lakukan dengan judul "Literasi Internet pada Siswa SMP" yang berlokasi di Kabupaten Purwakarta adalah sebuah penelitian yang dilaksanakan terhadap siswa SMPN 8 kelas 8, membahas bagaimana tingkat literasi internet pada siswa SMPN 8 kelas 8 Kabupaten Purwakarta. Penelitian dilakukan secara deskriptif kualitatif.

\section{Perkembangan Internet}

Sejarah internet dimulai pada Agustus 1962 dan penciptaan internet pertama kali dikemukakan oleh J.C.R. Licklider dari MIT Massachutts Institute of Technology. Konsep awal dinamakan "Galactic Network", ia mengemukakan tentang jaringan global yang memungkinkan orang dapat mengakses data dan program dari mana saja. Oktober 1962 beliau mengepalai program penelitian komputer di ARPA yang merupakan bagian dari Departemen Pertahanan Amerika Serikat.

Pada tahun 1971 protokol Telnet dan FTP berhasil dibangun. Pada tahun 1972 Larry Roberts dan Bob Kahn mengenalkan ARPANET pada konferensi ICCC yang diselenggarakan di Washignton. Pada tahun ini pula ARPANET menggunakan NCP untuk menstransfer data. ARPA berubah nama menjadi DARPA (Severin dan Tankard, 2007).

Pada tahun 1971 protokol Telnet dan FTP berhasil dibangun. Pada tahun 1972 Larry Roberts dan Bob Kahn mengenalkan ARPANET pada konferensi ICCC yang diselenggarakan di Washington. Ray Tomlinson menulis program yang memungkinkan surat elektronik dikirimkan ke jaringan ARPANET. Beliaulah yang merancang konversi “user@host.” Pada tahun ini pula ARPANET menggunakan NCP untuk menransfer data. ARPA berubah nama 
menjadi DARPA. ARPANET melakukan koneksi internasional yang pertama dengan University College of London dan Royal Establishment di Norwegia.

Pada tahun 1982 DCA atau Defense Communication Agency dan DARPA membentuk protokol yang disebut TCP/IP untuk ARPANET. Selanjutnya, Departemen Pertahanan Amerika Serikat menyatakan TCP/IP sebagai sebuah standar. Saat itulah internet didefinisikan sebagai sekumpulan jaringan yang terhubung yang menggunakan TCP/IP sebagai protokol.

Pada tahun 1988 Internet Relay Chat disingkat IRC dibuat oleh Jakko Oikarinen yang berguna untuk melakukan chatting secara online melalui komputer.

Pada tahun 1989 Australia, Jerman, Israel, Italia, Jepang, Mexico, Belanda, Selandia Baru, dan Inggris bergabung ke internet. Jaringan bernama JUNET di Jepang mulai berhubungan dengan NSFnet. Pada tahun 1989, TIM Berners Lee periset dari Inggris yang bekerja di CERN, Swiss, mengajukan konsep yang disebut sistem hypertext. Sistem ini mungkinkan melihat dokumen secara melompat-lompat dan bisa berjalan dalam sistem operasi yang berbedabeda. Konsep inilah yang disebut world wide web atau dikenal dengan nama web (Artikeltik, 2013).

\section{Manfaat dan Dampak Negatif Internet}

Internet (Interconnected) merupakan sebuah sistem komunikasi global yang menghubungkan komputer-komputer dan jaringan-jaringan di seluruh dunia tanpa mengenal teritorial, budaya, dan hukum untuk menyebarkan informasi dan mendapatkan informasi (Anonim, 2013).

Manfaat Internet adalah 1) Bidang pendidikan, sebagai media pembelajaran secara online dengan menggunakan teleconference internet (e-learning); 2) Bidang ekonomi dan bisnis, internet hadir dengan istilah e-commerce yaitu kegiatan perdagangan, jual beli, promosi, dan sebagainya dapat dilakukan melalui internet; 3) Bidang pemerintahan, internet hadir dengan e-government untuk memudahkan pemerintah dalam memberikan informasi dan layanan kepada masyarakat secara maksimal; 4) Sarana bersosialisasi dan mencari sahabat, pengguna internet dapat menjalin komunikasi dengan rekan-rekannya di segala penjuru dunia dalam waktu singkat dan biaya murah melalui fasilitas email dan chatting; 5) Sarana hiburan, internet menyediakan banyak fasilitas pilihan seperti permainan, game, musik, video, dunia entertainment, dan sebagainya. Sementara itu dampak negatif internet: pornografi, ancaman virus, ketergantungan jaringan, memengaruhi kultur budaya, tindak kejahatan, kekejaman dan kesadisan, perjudian (Anonim, 2013).

Kekuatan internet, bukan sekadar pada kecanggihan hardware tetapi juga pada kerumitan softwarenya. Aplikasi software komunikasi dan kolaborasi koneksi digunakan untuk mendukung komunikasi, koordinasi, dan kolaborasi jaringan yang ada dalam cyber communication. Sebagai contoh, aplikasi ini meliputi beberapa macam seperti dijelaskan oleh Kadir dalam Bungin (2008), sebagai berikut: surat elektronis, surat bersuara (voice mail), forum diskusi, sistem percakapan tertulis (chat), konferensi suara, konferensi video, sistem pertemuan elektronik (GSS).

Internet sebagai komunikasi bermedia komputer atau Computer Mediated Communication (CMC) merupakan bidang komunikasi yang luas yang memberikan layanan kepada audiensnya. Audiens melakukann penelitian, bermain games, download musik atau film, menjaga hubungan dengan keluarga mencari kesamaan lainnya, membeli produk, dan melakukan aktivitas lainnya Barne dalam Rahman, 2010).

Sementara itu, internet dalam konteks media baru memiliki definisi yang meliputi:

1. Jaringan infrastruktur teknologi yang saling terhubung untuk mendukung word wide web;

2. Situs-situs resmi yang terhubung dalam web;

3. Arsitektur dan software baik yang bersumber terbuka maupun tertutup, seperti firefox, wikipedia, internet 
explorer, google;

4. Komputer dan bahasa sehari-hari yang membuat internet dapat diakses oleh orang dari berbagai budaya dan literasi;

5. Email, chat, instant messaging (AOL, MSN);

6. Blog dan situs jejaring sosial;

7. Games, komunitas, lingkungan, dan dunia;

8. Berbagai cara komunikasi yang dimediasi secara digital yang telah meluas dalam kehidupan sehari-hari (Green dalam Mudjiyanto, 2012).

Dari definisi di atas dapat diketahui bahwa begitu banyak hal yang dapat dilakukan melalui media baru. Hal ini dimungkinkan karena seperti dikatakan Feldman dalam Flew mengatakan, media baru itu memiliki karakteristik: 1) Manipulable (mudah dibagi dan dipertukarkan antara banyak pengguna secara bersamaan dan melewati jarak yang jauh sekaligus); 2) Dense (jumlah informasi digital yang besar dapat disimpan dalam ruang fisik kecil); 3) compressible (kapasitas informasi dapat diringkas sesuai kebutuhan); dan 4) Impartial (informasi) digital mudah disebarkan jaringan tanpa peduli dalam bentuk apa informasi tersebut diwakilkan, siapa yang memiliki atau membuat informasi tersebut, atau untuk apa informasi tersebut akan digunakan. Karenanya, melalui media baru masyarakat dapat memeroleh informasi dari seluruh dunia melalui berbagai situs yang terhubung dalam $w e b$. Selain itu masyarakat bisa saling berbagi informasi serta saling berkomunikasi melalui berbagai fasilitas yang terdapat di blog, email, instant messaging, serta situs jejaring sosial (Mudjiyanto , 2012).

\section{Gagasan McLuhan tentang Media Baru}

McLuhan (1968) memberikan gagasan yang kaya untuk melakukan riset tentang media baru. Gagasan inti bahwa the medium is the message dapat diaplikasikan pada internet atau bentuk-bentuk khusus word wide web, seperti situs-situs berita online. Gagasan McLuhan tentang "desa global" tampaknya semakin dekat pada realita dengan internet.
McLuhan juga mencetuskan berbagai gagasan cerdas tentang perbedaan antara bentukbentuk media. Penelitian yang membandingkan media online dengan tradisional dalam menyampaikan informasi.

Sejauh ini belum terlihat teori baru yang dikembangkan dengan Internet dan Word wide web. Banyak riset pada komunikasi cyber telah dilakukan dengan pertanyaan-pertanyaan spesifik, terutama tentang efek dan manfaat media baru. Konsep ini dari interaktivitas, hypertexs, dan multimedia juga telah menjadi fokus berbagai penelitian. Satu teori yang telah dikembangkan adalah pemikiran Roger Fidler tentang mediamorfosis, yang berusaha menjelaskan hubungan antara media baru dengan media lama. Fidler telah mempresentasikan tentang gagasan mediamorfosis untuk membantu memahami jenis perubahan di bidang media ini. Mediamorfosis sendiri diartikan sebagai "perubahan bentuk media komunikasi, biasanya disebabkan oleh interaksi kompleks dari kebutuhan-kebutuhan penting, tekanantekanan kompetitif dan politis, dan inovasiinovasi sosial dan teknologi" (Severin dan Tankard, 2007).

\section{Literasi Internet}

Melalui medium internet banyak hal dapat dilakukan oleh penggunanya. Meskipun demikian seseorang yang akan menggunakan internet harus memunyai kemampuan untuk menggunakannya agar dicapai hasil yang efektif dan efisien dalam berkomunikasi dan mendapatkan informasi. Kemampuankemampuan itu secara terminologis disebut dengan literasi ICT (TIK). Literasi tersebut juga mengandung makna di dalamnya termasuk menguasai komponen literasi teknikal dan literasi informasi.

Internet literacy sendiri memiliki banyak pengertian, dan di antaranya diartikan Doyle sebagai kemampuan dalam menggunakan pengetahuan teori dan praktik dalam hubungannya dengan internet sebagai medium komunikasi dan pengelolaan informasi. Perbedaan definisi pada computer literacy dalam (Mudjiyanto, 2012) terletak 
pada:

1. Pengetahuan teoretis dan praktik tentang komputer (hardware, software) dan internet (komunikasi, pencarian informasi);

2. Keyakinan diri mengenai komputer dan internet;

3. Penggunaan yang bertanggungjawab dan refleksi kritis mengenai komputer dan internet.

Perbedaan di antara definisi computer literacy dan internet literacy tersebut di atas, terletak pada sisi, literasi komputer berhubungan dengan kemampuan mengetahui, memahami, dan mempraktikan komponen hardware dan software computer yang dibutuhkan untuk memanfaatkan fungsi komputer (misal untuk word processing maupun untuk beraktivitas komunikasi dan informasi melalui medium internet). Sementara literasi internet yaitu kemampuan untuk melakukan aktivitas komunikasi, pencarian informasi dan sejenisnya melalui medium internet guna memenuhi kebutuhan yang dimungkinkan terjadi hanya bila seseorang telah memiliki literasi komputer (Mudjiyanto, 2012).

Sesuai dengan zamannya, maka tumbuhnya e-literacy pada setiap generasi akan berbeda. Setiap negara terdiri dari masyarakat dengan beragam tingkat $e$ literacy/ICT literacy yang berbeda. Untuk menjawab permasalahan tersebut ada tiga tahapan strategi sebagai pendekatan efektif guna mengakselerasi peningkatan, yaitu:

1. Menciptakan konteks (demand creation);

2. Melibatkan teknologi (supply technology);

3. Mengubah perilaku (behaviour change).

Kemampuan e-literacy pada setiap individu akan memiliki pola yang berbeda sesuai dengan kebutuhan hidup dan kedewasaan masyarakat. (Departemen Komunikasi dan Informatika RI, 2006).

Menurut Personal Capability Maturity Model (P-CMM), level e-literacy seseorang dapat digambarkan kurang lebih seperti demikian:

Level 0, jika seorang individu sama sekali tidak tahu dan tidak peduli akan pentingnya informasi dan teknologi untuk kehidupan sehari-hari.

Level 1, jika seorang individu pernah memiliki satu dua kali pengalaman di mana informasi merupakan komponen penting untuk mencapai keinginan dan memecahkan masalah serta telah melibatkan teknologi informasi ataupun komunikasi untuk mencarinya.

Level 2, jika seorang individu telah berkali-kali menggunakan teknologi informasi dan komunikasi untuk membantu aktivitasnya sehari-hari dan telah memiliki pola perulangan dalam penggunaannya.

Level 3, jika seorang individu telah memiliki standar penguasaan dan pemahaman informasi ataupun teknologi yang diperlukannya serta konsisten mempergunakan standar sebagai acuan penyelenggaraan aktivitas sehari-hari.

Level 4, jika seorang individu telah sanggup meningkatkan secara signifikan kinerja aktivitas kehidupannya sehari-hari melalui pemanfaatan informasi dan teknologi.

Level 5, jika seorang individu telah mengganggap informasi dan teknologi sebagai bagian tidak terpisahkan dari aktivitas sehari-hari serta secara langsung maupun tidak langsung telah mewarnai perilaku dan budaya hidupnya (bagian dari information society) (Mudjiyanto, 2012).

Tiga tahap literasi internet (melek internet) sesuai juga untuk tiga sikap yang berbeda dan peran secara online:

1. Keterampilan dasar - terutama penggunaan pasif oleh mereka pengguna internet untuk mencari informasi secara online.

2. Keterampilan moderat - kombinasi penggunaan aktif dan pasif oleh mereka yang menggunakan internet dalam pencarian informasi online;

3. Keterampilan lanjutan - kombinasi penggunaan teknis aktif dan pasif oleh mereka yang mencari informasi online (Ciolek, 2003). 


\section{Kerangka Penelitian}

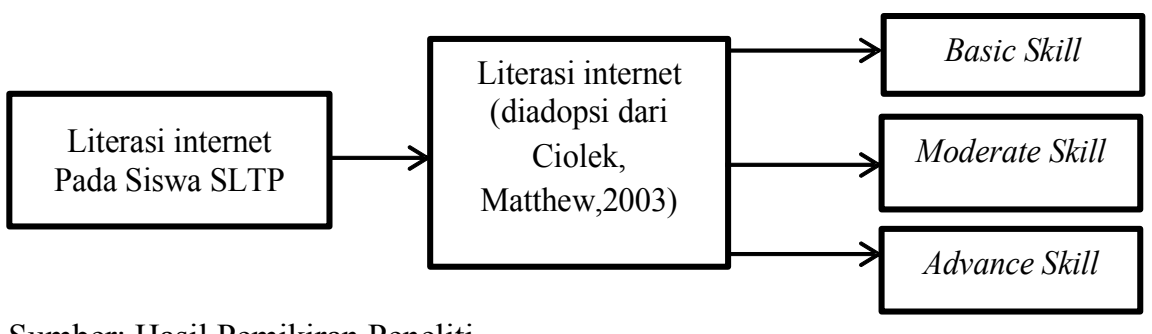

Sumber: Hasil Pemikiran Peneliti

\section{Gambar 1 \\ Kerangka Pemikiran}

Dalam penelitian ini literasi internet dibatasi dalam dua tahap yaitu basic skill dan moderate skill:

Basic Skill yang terdiri dari: mengirim/menerima email pribadi; menyelesaikan survei online; menggunakan chat room; menggunakan group/milis news; melakukan online banking; berpartisipasi dalam telepon internet; mencari-cari informasi secara online; berpartisipasi dalam konferensi video; bermain game multi-user online;

Moderate Skill yang terdiri dari: memublikasikan online dokumen elektronik; membuat/memublikasikan informasi secara online; membuat/memublikasikan data digital; membuat/memublikasikan berita online; membuat/menerbitkan panduan online ke sumber daya internet.

\section{METODE PENELITIAN}

Pendekatan penelitian ini adalah deskriptif kualitatif dengan menggunakan metode deskriptif eksploratif. Pengumpulan data melalui wawancara dan observasi, sehingga dapat diketahui bagaimana tingkat literasi internet siswa SMPN 8 di Kabupaten Purwakarta.

Dengan menggunakan pendekatan kualitatif diharapkan dapat diperoleh pemahaman yang mendasar (verstehen) terhadap masalah-masalah sosial secara holistik dan impresif dengan menggabungkan analisis dan interpretasi data yang ditampilkan secara naratif. Hal ini sejalan dengan pendapat Creswell yang menyatakan bahwa pendekatan kualitatif merupakan sebuah proses penyelidikan untuk memahami masalah sosial atau masalah manusia berdasarkan pada penciptaan gambaran holistik lengkap yang dibentuk dengan kata kata, melaporkan pandangan informan secara terperinci dan disusun dalam sebuah latar alamiah (Creswell, 2002).

Penelitian kualitatif dilakukan untuk menemukan gambaran yang menyeluruh dan mendalam tentang objek yang diteliti, dengan berangkat dari suatu fenomena yang ada, penelitian ini juga tidak berangkat dari suatu teori yang hendak diuji kebenarannya (Alwasilah, 2005).

Instrumen penelitian dilakukan sendiri oleh penulis, karena penulis merupakan instrumen utama (instrumen tunggal) dalam penelitian (Nasution dalam Sugiyono, 2008).

Teknik analisis data, dianalisis secara deskriptif kualitatif, lalu disajikan dalam bentuk naratif. Sementara lokasi penelitian di SMPN 8 Kabupaten Purwakarta.

Penentuan informan dan jumlahnya dilakukan sesuai dengan kebutuhan dalam penelitian. Informan adalah para pengguna internet baik yang memunyai komputer atau yang tidak memunyai komputer dari siswa SMP Negeri 8 Kabupaten Purwakarta.

Sampel untuk informan yang diwawancara mendalam masing-masing 2 orang dari tiap kelas 8 SMP tersebut. Sampel diambil kelas 8 karena kelas 9 tidak ada pada saat penelitian, sementara siswa kelas 7 tidak dijadikan sampel karena mereka termasuk siswa yang masih baru. Jumlah kelas 8 ada 7 kelas, sehingga jumlah informan menjadi 14 orang. Semua informan adalah 
pengguna internet dari SMPN 8 Kabupaten tabel 1 .

Purwakarta. Secara rinci, disajikan dalam

Tabel 1

Profil Informan

\begin{tabular}{ccc} 
No & Inisial informan & No HP \\
\hline 1 & F R & $087778737 \mathrm{xxx}$ \\
2 & D R D & $083820946 \mathrm{xxx}$ \\
3 & A G & $087779843 \mathrm{xxx}$ \\
4 & F D & $089611315 \mathrm{xxx}$ \\
5 & S P & $089639961 \mathrm{xxx}$ \\
6 & A S & $085772169 \times \mathrm{xxx}$ \\
7 & & $08971721 \mathrm{xxx}$ \\
8 & L G & $089605226 \mathrm{xxx}$ \\
9 & N A S & $0899376 \mathrm{xxx}$ \\
10 & N & $089696738 \mathrm{xxx}$ \\
11 & D HP & $089618653 \mathrm{xxx}$ \\
12 & S & $087779558 \mathrm{xxx}$ \\
13 & N & $085624840 \mathrm{xxx}$ \\
14 & A P & $087778903 \times x x$ \\
\hline
\end{tabular}

Sumber : Hasil Penelitian Mei 2013.

\section{HASIL PENELITIAN DAN PEMBAHASAN}

\section{Pengetahuan Informan tentang Internet}

Informan mengetahui tentang internet dari berbagai sumber. Seperti yang dikemukakan oleh salah satu informan yang mengatakan, bahwa dia mengetahui tentang internet dari teman-temannya yang telah mengetahui sebelumnya. Sumber informan mengetahui tentang internet adalah guru Teknologi Informasi dan Komunikasi (TIK), teman-teman sekolah, dan teman-teman sepermainan, serta kakak informan.

Dari hasil wawancara diketahui bahwa informan belajar tentang internet dari guru
TIK. Ini disampaikan informan DRD, $\mathrm{AG}$, FDA, DHP, dan SL. Sementara yang mengatakan bahwa yang mengajari internet kepada informan adalah guru sekolah dan teman-teman informan, baik teman di sekolah atau teman sepermainan, dikemukakan oleh informan FR, FDA, DHP, SL, NT, NAS, dan AP. Salah satu informan yang bernama FDA, mengatakan : "Yang mengajari saya untuk bisa mengakses internet adalah guru sekolah dan teman-teman. Awalnya saya hanya diajarin oleh guru TIK, namun setelah saya suka main internet di warnet; akhirnya saya juga diajarin oleh teman-teman; baik teman sekolah maupun teman sepermainan" (Wawancara dengan FDA, tanggal 2 Mei 
2013, di SMPN 8 Purwakarta).

Sementara tempat yang paling sering digunakan informan adalah warnet. Semua informan mengatakan bahwa tempat yang sering digunakan untuk mengakses internet adalah warnet. Salah satu informan DHP mengatakan "Kalau mengerjakan tugas dari sekolah, saya suka di warnet. Begitu juga kalau saya mau chatting atau facebook-an, saya biasanya ke warnet. Hampir setiap hari saya ke warnet" (wawancara di SMPN 8 Purwakarta, tanggal 3 Mei 2013). Informan yang lainnya AG mengatakan "Di samping untuk mengerjakan tugas dari sekolah yang ada hubungannya dengan internet, saya juga sering ke warnet untuk bermain game multiuser online" (Wawancara dengan AG tanggal 2 Mei 2013, di SMPN 8 Purwakarta).

Waktu yang informan habiskan setiap kali mengakses internet antara satu sampai dua jam dalam setiap kali mengakses internet. Namun, mereka mengakses internetnya tidak setiap hari (para informan tidak setiap hari mengakses internet). Mereka mengakses apabila ada tugas dari sekolah atau sedang ada waktu senggang. Seperti yang disampaikan oleh salah satu informan RZ, dia mengatakan, "Kalau ada tugas dari sekolah terutama yang menyangkut pelajaran yang ada hubungannya dengan internet, saya suka mencari-cari bahan pelajaran di warnet. Waktu yang saya habiskan, antara satu sampai dua jam" (Wawancara dengan RZ, tanggal 3 Mei 2013, di SMPN 8 Purwakarta).

Biaya yang dikeluarkan informan sekitar tiga ribu rupiah, sampai lima ribu rupiah. Pernyataan itu disampaikan oleh salah satu informan SP yang mengatakan, "Kalau saya mengunjungi warnet untuk menyelesaikan tugas dari guru sekolah, saya suka menghabiskan biaya sebesar tiga ribu rupiah. Itu cukup untuk satu jam mengakses internet. Saya mengunjungi warnet hanya kadang-kadang saja apabila ada tugas atau untuk sekedar facebookan" (Wawancara dengan SP, tanggal 2 Mei 2013, di SMPN 8 Purwakarta). Mereka mengeluarkan biaya untuk warnet itu dari uang jajan sendiri atau dari orang tua sebagai uang tambahan.

\section{Pemahaman dan Penguasaan Internet}

Berdasarkan hasil wawancara dengan informan dapat dikemukakan bahwa yang sudah memahami dan menguasai internet hanya dua informan. Salah satunya adalah DRD, yang mengatakan, "Saya memahami internet karena saya belajar sejak Sekolah Dasar sampai sekarang di SMP. Di samping itu, saya suka nanya ke guru TIK kalau ada yang tidak mengerti" (Wawancara dengan DRD, tanggal 2 Mei 2013, di SMPN 8 Purwakarta).

Sementara mengenai penguasaan informan tentang internet, banyak informan yang hanya sedikit menguasai internet, seperti dinyatakan oleh salah satu informan SP antara lain, "Saya tidak memahami dan menguasai internet secara menyeluruh, saya hanya sedikit menguasai internet, meskipun sejak sekolah dasar telah mengenal apa itu internet" (Wawancara dengan SP, tanggal 2 Mei 2013, di SMPN 8 Purwakarta).

Hal yang sama dikemukakan oleh informan AS dan DHP. Mereka juga sama seperti SP, mengenal internet sejak mereka duduk di bangku Sekolah Dasar. Salah satu informan yang bernama AS mengatakan, "Saya sudah tahu internet sejak saya duduk di bangku Sekolah Dasar, namun hanya sekedar mengetahui saja. Saya tidak memahami dan menguasai internet secara lengkap, saya hanya sedikit menguasai dan memahami internet" (Wawancara dengan AS, tanggal 2 Mei 2013, di SMPN 8 Purwakarta).

Dengan demikian secara keseluruhan, terlihat bahwa pemahaman dan penguasaan internet oleh informan masih kurang. Mereka hanya memahami dan menguasai internet secara dasar (basic skill).

\section{Pemahaman dan Penguasaan Menengah (Moderate skill)}

Pemahaman dan penguasaan internet oleh informan berdasarkan hasil penelitian menyatakan bahwa sebagian kecil informan yang memahami dan menguasai secara menengah. Hal ini terbukti dari jawaban informan yang antara lain menyatakan :

1. Semua informan menyatakan tidak pernah memublikasikan secara online 
dokumen elektronik.

2. Mereka tidak mengerti tentang dokumen elektronik secara online. Beberapa informan pernah membuat/memublikasikan informasi secara online.

3. Hanya ada beberapa informan yang pernah membuat data digital. Hampir semua informan tidak pernah membuat/memublikasikan berita online. Bahkan mereka tidak mengerti tentang cara membuat/memublikasikan berita online.

4. Semua informan menyatakan tidak pernah membuat/menerbitkan panduan online ke sumber daya internet.

\section{Pembahasan}

Pemahaman dan penguasaan internet menurut Ciolek, dalam makalahnya The Internet and its users: The physical dimensions of cyberpolitics in Eastern Asia tahun 2003 ada tiga tingkatan pemahaman internet, namun yang dibahas dalam penelitian ini hanya dua tingkatan saja, yaitu pemahaman dan penguasaan internet secara dasar (basic skill) dan menengah (moderat skill).

Ada beberapa ciri tentang penguasaan internet yang termasuk dalam penguasaan dasar (basic) antara lain: bisa mengunduh, mengirim/menerima email pribadi, menyelesaikan survei online, menggunakan chat room, menggunakan group/milis news, melakukan online banking, berpartisipasi dalam telepon internet, mencari-cari informasi secara online, berpartisipasi dalam konferensi video dan bermain game multiuser online.

Secara keseluruhan pemahaman dan penguasaan internet dapatlah dikemukakan bahwa sebagian besar informan telah memahami dan menguasai dasar tentang internet, namun masih ada informan yang belum menguasai dan memahaminya.

Hal ini wajar karena siswa SMPN 8 yang menjadi informan telah belajar internet sejak mereka Sekolah Dasar, namun mereka hanya sebatas untuk mengetahui secara dasar seperti mencari informasi untuk kegiatan dan tugas sekolah serta untuk facebookan (online facebook).

Sementara pemahaman dan penguasaan internet oleh siswa yang menjadi informan, hanya sebagian kecil yang memahami dan menguasai internet secara menengah (moderate skill).

Moderate skill merupakan keterampilan moderat - kombinasi penggunaan aktif dan pasif oleh mereka yang menggunakan internet dalam pencarian informasi online. Ciri penguasaan internet yang termasuk dalam penguasaan moderate skill antara lain, memublikasikan online dokumen elektronik, membuat/memublikasikan informasi secara online, membuat/memublikasikan data digital, membuat/memublikasikan berita online, dan membuat/menerbitkan panduan online ke sumber daya internet.

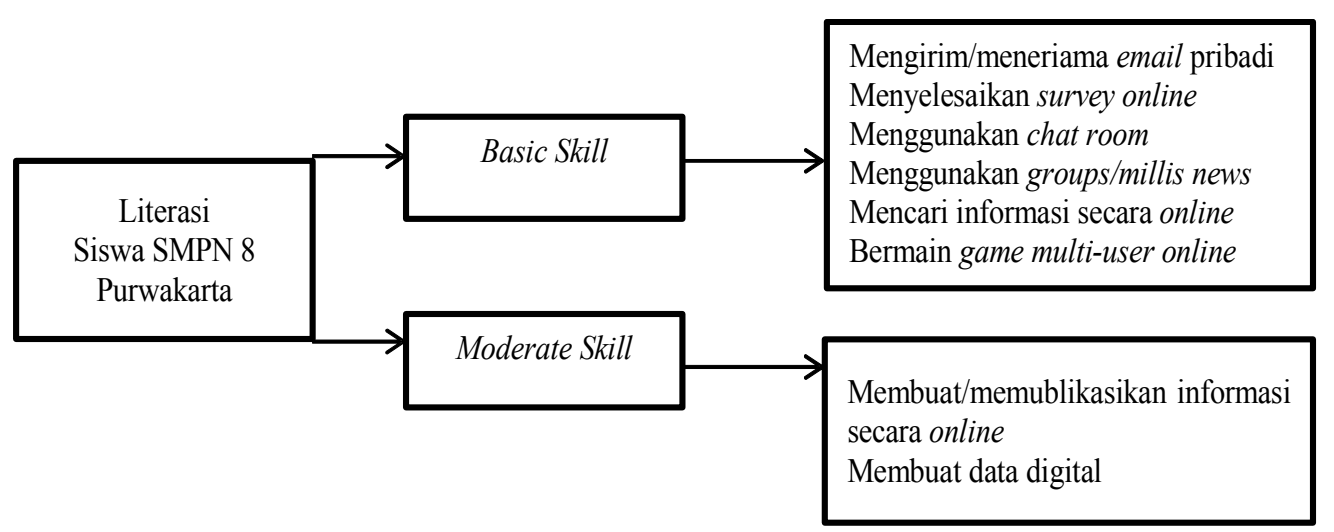

Hasil penelitian 2013.

Gambar 2

Model Literasi Internet pada Siswa SMPN 8 Purwakarta 


\section{PENUTUP}

\section{Simpulan}

Pemahaman dan penguasaan dasar (basic skill) tentang internet, hampir seluruh informan telah memahami dan menguasai dasar tentang internet, namun masih ada informan yang belum menguasai dan memahaminya.

Pemahaman dan penguasaan menengah (moderate skill) tentang internet, ada beberapa informan yang menguasai dan memahami dua item saja, dari lima item moderate skill, seperti pernah membuat/memublikasikan informasi secara online, dan membuat/memublikasikan berita online. Satu item lagi hampir semua informan tidak memahami dan menguasainya dalam hal membuat/memublikasikan berita online. Berarti penguasaan informan terhadap internet pada level moderat masih belum menguasai secara keseluruhan.

\section{Saran}

Para siswa SMPN 8 Kabupaten Purwakarta diharapkan dapat meningkatkan pemahaman dan penguasaannya terhadap internet secara berjenjang, dengan meningkatkan pengetahuan mereka terhadap internet.

Level penguasaan internet, para siswa SMPN 8 Kabupaten Purwakarta (Informan) tidak hanya berhenti pada basic skill dan moderat skill, sebaiknya bisa berlanjut ke level selanjutnya seperti advance skill secara bertahap.

\section{DAFTAR PUSTAKA}

\section{Buku :}

Alwasilah, Chaedar. (2003). Pokoknya Kualitatif, Dasar Dasar Merancang Dan Melakukan Penelitian Kualitatif.Bandung: Pustaka Jaya.

Bungin, Burhan.(2008). Sosiologi Komunikasi, Teori, Paradigma, dan Diskursus Teknologi Komunikasi di
Masyarakat. Jakarta: Kencana Predana Media Group.

Cresswell, John W. (2002). Research Design Qualitative And Quantitative Approches. Desain Penelitian, Pendekatan Kualitatif dan Kuantitatif. Jakarta: Kil Pers.

Iriantara, Yosal. (2009). Literasi Media. Apa, Mengapa, Bagaimana. Bandung: Penerbit Simbiosa Rekatama Media.

McLuhan, Marshall. (1968). War and Peace in the Global Vilage. USA: Bantam Book Inc.

Severin, J Werner dan James W. Tankard, Jr. (2007). Teori Komunikasi, (Sejarah, Metode, dan Terapan di Dalam Media Massa). Penerjemah, Sugeng Hariyanto. Jakarta: Kencana Predana Media Group.

Sugiyono. (2008). Memahami Penelitian kualitatif. Bandung: CV. Alfabeta.

\section{Jurnal:}

Haryati. (2011). Studi Literasi Informasi Pada Pegawai Negeri Sipil (PNS) Tenaga Pendidik. Jurnal Penelitian Komunikasi. Bandung: BPPKI. Vol. 14 No. 2. hal. 111-126.

Rahman, A. Harahap. (2010). Literasi Internet Dan Peningkatan Ilmu Pengetahuan. Jurnal Pikom Penelitian komunikasi dan Pembangunan. Medan Balai besar Pengkajian Dan Pengembangan Komunikasi dan Informatika. Vol. 11 No. 3. hal. 403 - 426.

Mudjiyanto, Bambang. (2012). Literasi Internet Dan Partisipasi Politik Masyarakat Pemilih dalam Aktivitas Pemanfaatan Media Baru. Jurnal Studi Komunikasi Dan Media. Jakarta: BPPKI. Vol. 16 No. 1. hal. 1-15.

\section{Internet:}

Anonim. (2013). Dampak Negatif Internet. Tersedia dalam http://artikelterkait.com/dampaknegatif-internet.html, diakses pada tanggal 1 Juli 2013.

Artikeltik.(2013). Sejarah Internet. tersedia dalam 
$<$ http://www.artikeltik.com/sejarahinternet.html $>$, diakses tanggal 25 November 2013.

Ciolek, T. Matius. (2003). The Internet and its users: The physical dimensions of cyberpolitics in Eastern Asia, tersedia dalam www.ciolek.com/PAPERS/oregon2003-HYPERLINK

-text.html"'http://www.ciolek.com/PAP ERS/oregon-2003-text.html"text.html>, diakses pada tanggal 19 April 2013.

Departemen Komunikasi dan Informatika RI. (2006). The Strategic Blue Print of Planning And Develoving The ICT-
Literate Resources in Indonesia, Version 1.0. Jakarta: Depkominfo. Tersedia dalam $<$ https://www.academia.edu/4139703/ Literasi TIK dimuat di widyariset

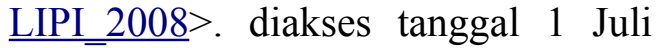
2013.

Siahaan, Shella Anne Tryssa P. (2010) Penelitian, Pemanfaatan Internet. tersedia dalam $<$ http://repository.usu.ac.id/handle/1234 $56789 / 21328>$, diakses pada tanggal 28 Januari 2013. 